\title{
ANALISIS LOAN TO DEPOSIT RATIO, NON PERFORMING LOAN, NET INTEREST MARGIN TERHADAP PROFITABILITAS BANK
}

\author{
Nia Tresnawaty ${ }^{1}$ \\ ${ }^{1}$ Universitas Satya Negara Indonesia \\ e-mail: 1niatresna@yahoo.com

\begin{tabular}{ccc}
\hline Diterima & Direvisi & Disetujui \\
$31-01-2022$ & $16-02-2022$ & $23-02-2022$ \\
\hline
\end{tabular}

\begin{abstract}
Abstrak - Penelitian dilakukan guna menguji bagaimana pengaruh variable Loan to Deposit Ratio (LDR), Non Performing Loan (NPL) dan Net Interest Margin (NIM) terhadap Profitabilitas pada Bank Konvensional dengan populasi perusahaan sektor perbankan umum yang tercatat di Bursa Efek Indonesia kurun waktu 2015-2019. Metode yang digunakan dalam Penelitian dengan menggunakan analisis regresi linear berganda, design penelitian menggunakan kausal dan jenis data yang digunakan adalah data sekunder. Dari pengolahan data disimpulkan bahwa Non Performing Loan (NPL) dan Net Interest Margin (NIM) berpengaruh terhadap Profitabilitas Bank, sementara Loan to Deposit Ratio (LDR) tidak berpengaruh terhadap Profitabilitas Bank.

Kata Kunci: LDR; NPL; NIM; PROFITABILITAS BANK
\end{abstract}

Abstract - This study was conducted to examine how the variables influence Loan to Deposit Ratio (LDR), Non Performing Loan (NPL) and Net Interest Margin (NIM) on Profitability at Conventional Banks with a population of general banking sector companies listed on the Indonesia Stock Exchange for the period 2015-2019. . The method used in the study using multiple linear regression analysis, research design using causal and the type of data used is secondary data. From data processing, it can be concluded that Non Performing Loans (NPL) and Net Interest Margin (NIM) have an effect on Bank Profitability, while Loan to Deposit Ratio (LDR) has no effect on Bank Profitability.

Keywords: LDR; NPL; NIM; BANK PROFITABILITY

\section{PENDAHULUAN}

Adanya pertumbuhan perekonomian domestik yang terjadi pada tahun 2019 memperlihatkan kecenderungan adanya perlambatan 5,02\% jika kita melihat data tahun 2018 yang menunjukkan angka pertumbuhan sebesar $5,17 \%$. Perlambatan pertumbuhan tersebut dikarenakan adanya pertumbuhan yang lambat dalam investasi dan didukung oleh pengeluaran serta kinerja ekspor yang juga belum pulih meskipun konsumsi masih dalam kondisi yang cukup baik. Begitu juga jika dilihat dari sisi ekonomi perbankan, adanya perlambatan pertumbuhan ekonomi domestic ini dapat terlihat dalam pertumbuhan kredit yang moderat yaitu sebesar 6,08\% jika dibandingkan dengan pertumbuhan pada tahun sebelumnya yaitu sebesar $11,75 \%$.

Namun dengan kondisi seperti yang dijelaskan tersebut diatas, fungsi intermediasi perbankan masih tetap berjalan dengan baik. Hal tersebut seiring dengan kondisi likuiditas yang memadai dengan disertai adanya pertumbukan DPK sebesar 6,54\% yang mengalami peningkatan jika dibandingkan dengan tahun lalu sebesar $6,45 \%$. 
Penyaluran kredit kepada masyarakat atau nasabah merupakan sumber pendapatan utama dari Bank. Rasio nilai kredit yang dikeluarkan oleh Bank dengan sejumlah dana masyarakat serta modal sendiri diukur dengan melihat nilai LDR. Peraturan Bank Indonesia No.15/7/PBI/2013 menyatakan batas tertinggi LDR92\%, batas terendah LDR sebesar 78\%. Jika rasio LDR lebih kecil dari batas bawah atau sebaliknya, maka hal tersebut harus sangat diperhatikan oleh perusahaan atau Bank.

Penyaluran kredit kepada masyarakat atau nasabah memiliki resiko bagi dunia perbankan meskipun hal tersebut menjadi sumber penghasilan suatu Bank. Sehingga Bank di tuntut untuk memiliki kemampuan untuk mengelola kredit macet atau bermasalah. Kinerja suatu Bank dalam mengelola kredit macet atau bermasalah dapat diketahui melalui Non Performing Loan Rasio (NPL). Jika nilai Rasio NPL tinggi maka artinya tingkat penyaluran kredit suatu Bank akan semakin turun atau memburuk. Dengan demikian dapat berakibat akan semakin besar jumlah kredit yang bermasalah yang berdampak semakin besarnya masalah yang dihadapi.

Kinerja Bank dalam menghasilkan pendapatan dari penyaluran kredit kepada masyarakat dapat dilihat dengan rasio keuangan yaitu Net Interest Margin (NIM). Adapun standar dalam PBI (Peraturan Bank Indonesia ) No.13/I/PBI/2011 adalah sebesar 5\% dari rata-rata perbankan.

Selain dalam penyaluran kredit, Bank juga harus dapat memanfaatkan aktiva yang dimilikinya untuk mendapatkan keuntungan. Dari sekian banyak indikator dalam mengukur kinerja Bank, yang sering digunakan adalah dengan menghitung Return On Asset (ROA). Rasio ini digunakann dalam menghitung kinerja perusahaan untuk memperoleh laba dengan menggunakan aset yang dimiliki sekaligus juga sebagai gambarandalam hal pengembalian perusahaan dari aktiva (pendanaan) yang diberikan oleh perusahaan.

\section{REVIU LITERATUR DAN HIPOTESIS Bank}

Bank merupakan sebuah badan usaha yang menampung dana yang berasal dari rakyat yang bias berbentuk tabungan, deposito atau berbentuk lainnya serta menyalurkannya kembali kepada rakyat dalam bentuk pinjaman (kredit) atau berbentuk lainnya untuk memajukan taraf hidup rakyat banyak, seperti yang terdapat dalam Undang Undang No.10 Tahun 1998.

\section{Profitabilitas}

Seperti kita ketahui bahwa untuk mengukur tingkat profitabiliatas salah satunya dengan melihat tingkat pengembalian aktiva atau biasa disebut ROA. Kasmir (2018:201) mendefinisikan bahwa Return On Asset digunakan untuk melihat nilai dari pengembalian bisnis atas jumlah asset yang digunakan. Rasio dapat menunjukkan tingkat efektivitas perusahaan untuk mendapatkan keuntungan dengan mengoptimalkan aset perusahaan. Return On Asset dapat dihitung sebagai berikut:

$$
\text { ROA }=\frac{\text { Penjualan Bersih }}{\text { Total Aset }} \times 100 \%
$$

\section{Loan to Deposit Ratio (LDR)}

Loan to Deposit Ratio untuk menghitung jumlah pinjaman yang dibagikan berbanding dengan jumlah simpanan dari masyarakat serta modal sendiri yang digunakan. Maka dapat dikatakan bahwa rasio ini mencerminkan kinerja Bank untuk membayar kembali kewajiban bank terhadap para nasabahnya. Dikemukakan oleh Kasmir (2018:290). Loan to Deposit Ratio dihitung sebagai berikut: 


\section{LDR $=$ Total Kredit Pihak Ketiga $\times 100 \%$ Total Dana Pihak Ketiga}

\section{Non Performing Loan (NPL)}

Kredit macet atau Non Performing Loan (NPL) merupakan keadaan dimana nasabah tidak mampu membayar pinjaman menurut jadwal pembayaran yang sudah disepakati dalam jangka waktu tertentu. Seperti halnya yang dikemukakan oleh Kasmir (2018:155) Non Performing Loan atau kredit macet merupakan kondisi dimana terjadi hambatan yang disebabkan oleh 2 faktor yakni dari pihak Bank dalam hal menganalisis dan pihak debitur tidak melakukan kewajiban pembayaran baik yang disengaja atau tidak disengaja. Standar NPL menurut Bank Indonesia adalah sebesar 5\%, apabila NPL melebihi dari nilai standar tersebut akan berpengaruh kepada tingkat kesehatan Bank (Peraturan Bank Indonesia No. 20/8/PBI/2018).

Untuk menghitung rasio Non Performing Loans dapat dihitung :

$$
\text { NPL }=\frac{\text { Kredit Bermasalah }}{\text { Total Kredit }} \times 100 \%
$$

\section{Net Interest Margin (NIM)}

Dikemukakan oleh Kasmir (2018:220) bahwa rasio Net Interest Margin untuk mengukur kinerja manajemen suatu Bank dalam mengelola aktiva produktifnya untuk memperoleh pendapatan bunga bersih.

Bank Indonesia telah memberikan standar untuk rasio NIM sebesar 6\%. Adapun Rasio Net Interst Margin dapat dihitung :

$$
\mathrm{NIM}=\frac{\text { Pendapatan Bunga Bersih }}{\text { Aktiva Produktif }} \times 100 \%
$$

\section{Hubungan Antar Variabel dan Hipotesis}

\section{Rasio LDR (X1) Terhadap Profitabilitas Bank (Y)}

Dalam kaitannya antara LDR (X1) terhadap Profitabilitas Bank (Y) adalah terkait dengan kemampuan Bank untuk membayar kembali membayar kembali hutang bank terhadap para nasabah. Jika nilai LDR ini meningkat artinya tingkat likuiditas Bank akan semakin rendah. Namun jika kondisi sebaliknya yaitu jika rasio LDR menurun artinya tingkat likuiditas bank akan semakin tinggi. Selain itu, rasio ini dapat dijadikan indikator dalam memprediksi kerawanan serta kinerja Bank dalam menghasilkan pendapatan akibat adanya penyaluran kredit.

Ha1 : Loan to Debt Ratio berpengaruh terhadap Profitabilitas Bank.

\section{Rasio NPL (X2) Terhadap Profitabilitas Bank (Y)}

Hubungan antara NPL (X2) terhadap Profitabilitas Bank (Y) menunjukkan rasio kredit bermasalah terhadap total kredit. Standar maksimal NPL berdasarkan ketentuan Bank Indonesia sebesar 5\%, namun apabila di atas 5\% akan berpengaruh terhadap tingkat kesehatan Bank. Jika rasio NPL meningkat maka pendapatan yang tidak diterima oleh bank akan semakin besar, sehingga hal tersebut dapat mempengaruhi tingkat profitabilitas bank tersebut. 
Ha2 : Non Performing Loan berpengaruh terhadap Profitabilitas Bank.

\section{Rasio NIM (X3) Terhadap Profitabilitas Bank (Y)}

Hubungan antara NIM (X3) terhadap Profitabilitas Bank (Y), dimana NIM ini akan memperlihatkan kinerja bank untuk memanifestasikan pendapatan bunga bank bersih dalam memanfaatkan aktiva produktif. Jika rasio ini bernilai tinggi maka kinerja suatu bank di dalam menghasilkan pendapatan bunga akan semakin baik, selain itu jika rasio menunjukkan angka yang besar maka akan semakin tinggi juga penghasilan (pendapatan bunga) yang berasal dari aktiva produktif yang dikelola oleh Bank.

Ha3 : Net Interest Margin berpengaruh terhadap Profitabilitas Bank.

\section{METODE PENELITIAN}

\section{Desain Penelitian}

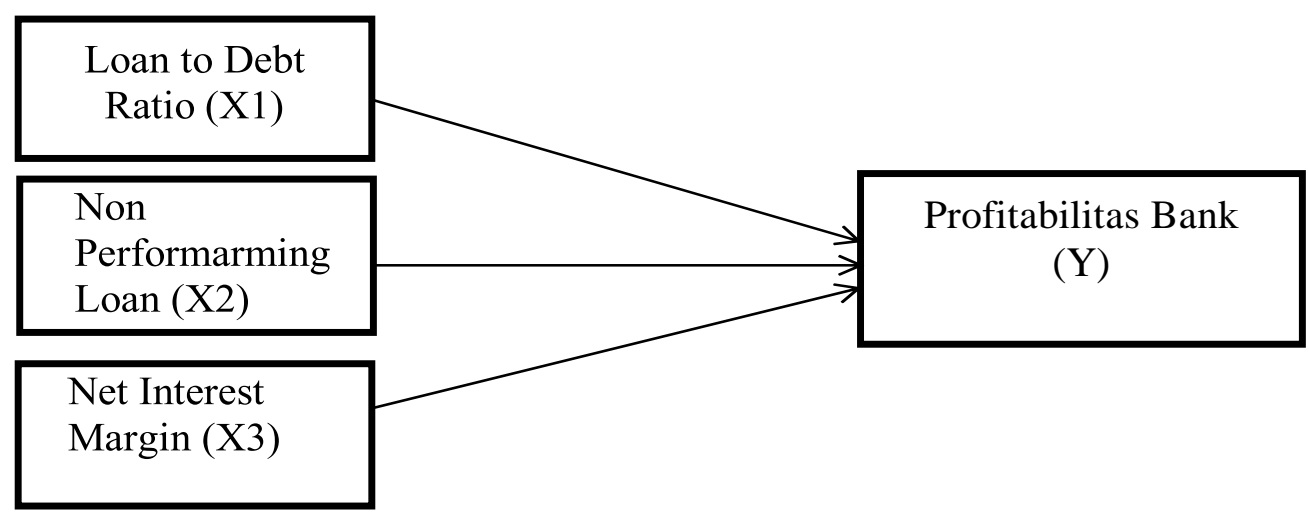

\section{Variabel Penelitian}

\section{Variabel Bebas $(\mathbf{X})$}

Variabel bebas yang di gunakan adalah:

Loan to Deposit Ratio (X1)

Non Performing Loan (X2)

Net Interest Margin (X3)

\section{Variabel Terikat (Y)}

Variabel terikat terdiri dari Profitabilitas Bank, dimana rasio Return On Assets (ROA) yang digunakan untuk mengukur Profitabilitas.

\section{HASIL DAN PEMBAHASAN}

\section{Jenis Data}

Penelitian menggunakan data sekunder dengan mendapatkan data-data dari Bursa Efek Indonesia 
Tabel 1. Descriptive Statistic

\begin{tabular}{|l|r|r|r|r|r|}
\hline \multicolumn{7}{|c|}{ Descriptive Statistics } \\
\hline & $N$ & Minimum & Maximum & \multicolumn{1}{c|}{ Mean } & Std. Deviation \\
\hline LDR & 112 & 55,34 & 115,26 & 88,5465 & 10,74857 \\
\hline NPL & 112 &, 00 & 4,20 & 1,5158 &, 86091 \\
\hline NIM & 112 & 3,32 & 9,30 & 5,4770 & 1,32950 \\
\hline Profitabilitas Bank & 112 &, 13 & 4,19 & 1,9306 &, 98468 \\
\hline
\end{tabular}

Sumber : Output SPSS,2021

\section{Uji Asumsi Klasik Normalitas}

Untuk menguji Normalitas data menggunakan perhitungan One Sample Kolmogorov Smirnov Test serta uji Normal Probability Plot atau P Plot, sebagai berikut:

Tabel 2. Uji One Sample Kolmogorov-Smirnov

\begin{tabular}{|l|l|r|}
\hline \multicolumn{2}{|c|}{ One-Sample Kolmogorov-Smirnov Test } \\
\hline \multicolumn{2}{|l|}{} & $\begin{array}{c}\text { Unstandardized } \\
\text { Residual }\end{array}$ \\
\hline N & Mean & 112 \\
\hline $\begin{array}{l}\text { Normal } \\
\text { Parameters, b }\end{array}$ & $\begin{array}{l}\text { Std. } \\
\text { Deviation }\end{array}$ &, 0000000 \\
\hline \multirow{2}{*}{$\begin{array}{l}\text { Most } \\
\text { Differences }\end{array}$} & Absolute &, 06154516 \\
\cline { 2 - 3 } & Positive &, 060 \\
\cline { 2 - 3 } & Negative &,- 044 \\
\hline Test Statistic &, 060 \\
\hline Asymp. Sig. (2-tailed) &, 200 c,d \\
\hline a. Test distribution isNormal. & \\
\hline b. Calculated from data. & \\
\hline
\end{tabular}

Sumber : Output SPSS,2021

Dengan melihat tabel olah data tersebut menunjukkan nilai signifikansi dari Unstandarized Residual tersebut adalah 0,200>0,05 artinya lebih besar dari 5\% sehingga dikatakan data yang digunakan dalam penelitian ini berdistribusi normal.

\section{Uji Multikolinearitas}

Pada tahap ini dilakukan agar dapat mengetahui apakah ditemukan model regresi korelasi antar variabel bebas. 


\section{Tabel 3. Multikoloniearitas}

\begin{tabular}{|l|l|r|c|}
\hline \multicolumn{3}{|c|}{ Coefficients $^{\mathbf{2}}$} \\
\hline \multirow{2}{*}{ Model } & Collinearity Statistics \\
\cline { 3 - 4 } & Tolerance & \multicolumn{1}{c|}{ VIF } \\
\hline 1 & LDR &, 973 & 1,028 \\
\cline { 2 - 4 } & NPL & .974 & 1,027 \\
\cline { 2 - 4 } & NIM & .992 & 1,008 \\
\hline \multicolumn{3}{|l|}{ a. Dependent Variable: Profitabilitas } \\
\hline
\end{tabular}

\section{Sumber : Output SPSS,2021}

Berdasarkan hasil olah data dalam tabel tersebut menghasilkan nilai tolerance dari masingmasing variabel bebas yaitu LDR (X1) sebesar 0,973 > 0,1, NPL (X2) sebesar 0,974>0,1 dan NIM (X3) yaitu 0,992 > 0,01 dan juga VIF dari variable X1 sampai X3 sebesar 1,028, 1,027 dan 1,008 $<10$, sehingga dapat dikatakan bahwa tidak terjadi multikolinearitas.

\section{Uji Heteroskedastisitas}

Tabel 4. Uji Gletjer

\begin{tabular}{|c|c|c|c|c|c|c|}
\hline \multicolumn{7}{|c|}{ Coefficientsa } \\
\hline & & \multicolumn{2}{|c|}{$\begin{array}{l}\text { Unstandardized } \\
\text { Coefficients }\end{array}$} & \multirow{2}{*}{\begin{tabular}{|l}
$\begin{array}{l}\text { Standardizeo } \\
\text { Coefficients }\end{array}$ \\
Beta
\end{tabular}} & \multirow[b]{2}{*}{$T$} & \multirow[b]{2}{*}{ Sig. } \\
\hline \multicolumn{2}{|c|}{ Model } & B & Std. Error & & & \\
\hline \multirow[t]{4}{*}{1} & (Constant) & 2,455 & 1,149 & & 2,136 & 035 \\
\hline & LDR &,- 416 &, 248 &,- 159 & $-1,677$ & 097 \\
\hline & NPL &, 048 &, 048 & 096 & 1,015 & 313 \\
\hline & NIM &,- 164 &, 136 &,- 114 & $-1,207$ & 230 \\
\hline
\end{tabular}

Sumber : Output SPSS,2021

Melihat nilai dari hasil olah data dalam tabel tersebut menghasilkan nilai signifikansi (Sig.) LDR (X1) bernilai 0,097 > 0,05, NPL (X2) bernilai 0,313 > 0,05 NIM (X3) bernilai 0,230 sehingga ditarik kesimpulan bahwa dalam uji ini tidak terjadi adanya gejala heteroskedastisitas. 


\section{Uji Regresi Linear Berganda}

Tabel 5. Regresi Linear Berganda

\begin{tabular}{|c|c|c|c|c|c|c|}
\hline \multicolumn{7}{|c|}{ Coefficients $^{a}$} \\
\hline \multirow{2}{*}{\multicolumn{2}{|c|}{ Model }} & \multicolumn{2}{|c|}{$\begin{array}{c}\text { Unstandardized } \\
\text { Coefficients }\end{array}$} & \multirow{2}{*}{$\begin{array}{c}\text { Standardized } \\
\text { Coefficients } \\
\text { Beta }\end{array}$} & \multirow[b]{2}{*}{$T$} & \multirow[b]{2}{*}{ Sig. } \\
\hline & & B & Std. Error & & & \\
\hline \multirow[t]{4}{*}{1} & (Constant) & $-4,753$ & 1,670 & & $-2,846$ &, 005 \\
\hline & LDR &, 578 &, 360 &, 114 & 1,605 & , 111 \\
\hline & NPL &,- 276 &, 069 &,- 284 & $-3,990$ &, 000 \\
\hline & NIM & 1,632 &, 197 &, 589 & 8,274 & ,000 \\
\hline
\end{tabular}

Sumber : Output SPSS,2021

Dengan melihat nilai olah data dalam tabel tersebut nilai konstanta a sebesar $-4,753$, koefisien regresi b1 adalah 0,578, koefisien regresi b2 adalah -0,276, dan koefisien regresi b3 adalah 1,632. Berikut ini merupakan persamaan regresi :

$$
Y=-4,753+0,578(X 1)-0,276(X 2)+1,632(X 3)+e
$$

\section{Uji Koefisien Determinasi}

Tabel 6. Koefisien Determinasi

\begin{tabular}{|l|r|r|r|r|r|}
\hline \multicolumn{7}{|c|}{ Model Sum m ary $^{\mathrm{b}}$} \\
\hline Model & $\mathrm{R}$ & R Square & $\begin{array}{c}\text { Adjusted R } \\
\text { Square }\end{array}$ & $\begin{array}{c}\text { Std. Error of the } \\
\text { Estimate }\end{array}$ & $\begin{array}{r}\text { Durbin- } \\
\text { Watson }\end{array}$ \\
\hline 1 &, $722^{\mathrm{a}}$ &, 521 &, 508 &, 69095543 & 1,963 \\
\hline \multicolumn{5}{|l}{} \\
a. Predictors: (Constant), LDR, NPL, N1M \\
\hline
\end{tabular}

Sumber : Output SPSS,2021

Dengan melihat nilai olah data dalam tabel di atas menghasilkan nilai R2 sebesar 0,508. Sehingga dapat ditarik kesimpulan bahwa variable dependen yaitu Profitabilitas Bank dapat dijelaskan oleh variable LDR, NPL dan NIM sebesar 58,8\% dan sisanya dipengaruhi variablevariabel lain yang belum masuk dalam penelitian. 


\section{Uji Statistik F}

Tabel 7. Uji Statistik F

\begin{tabular}{|l|l|l|l|l|l|l|}
\hline \multicolumn{7}{|c|}{ ANOVAa } \\
\hline \multicolumn{2}{|l|}{ Model } & Sum of Squares & & Mean Square & F & Sig. \\
\hline \multirow{2}{*}{1} & Regression & 15,051 & 3 & 5,017 & 24,302 & $000 \mathrm{~b}$ \\
\cline { 2 - 7 } & Residual & 21,883 & 106 & 206 & & \\
\cline { 2 - 7 } & Total & 36,934 & 109 & & & \\
\hline \multicolumn{2}{|l|}{ a. Dependent Variable: Profitabilitas } & & \\
\hline
\end{tabular}

Sumber : Output SPSS,2021

Nilai F hitung dari output spss adalah sebesar 24,302, nilai dari $\mathrm{F}$ tabel $=(\mathrm{k}$; n-k), F $(3 ;(112-$ 3)); $\mathrm{F}(3 ; 109)=2.69$ jika di bandingkan dengan $\mathrm{F}$ hitung akan diperoleh 24,302>2,69 artinya nilai $\mathrm{F}$ hitunng $>\mathrm{F}$ tabel sehingga Ha diterima/ semua variabel independent yang secara bersama-sama dapat mempengaruhi variabel dependen.

\section{Uji Parsial ( $t$ )}

Tabel 8. Uji t

\begin{tabular}{|c|c|c|c|c|c|c|}
\hline \multicolumn{7}{|c|}{ Coefficientsa } \\
\hline & & \multicolumn{2}{|c|}{$\begin{array}{l}\text { Unstandardized } \\
\text { Coefficients }\end{array}$} & $\begin{array}{l}\text { Standardized } \\
\text { Coefficients }\end{array}$ & \multirow[b]{2}{*}{$\mathrm{T}$} & \multirow[b]{2}{*}{ Sig. } \\
\hline \multicolumn{2}{|c|}{ Model } & $B$ & Std. Error & Beta & & \\
\hline \multirow[t]{4}{*}{1} & (Constant) & $-4,753$ & 1,670 & & $-2,846$ & ,005 \\
\hline & LDR &, 578 &, 360 & ,114 & 1,605 & 111 \\
\hline & NPL &,- 276 &, 069 &,- 284 & $-3,990$ & , 000 \\
\hline & NIM & 1,632 & 197 &, 589 & 8,274 & , 000 \\
\hline
\end{tabular}

Sumber : Output SPSS,2021

\section{Hasil dan Interpretasi}

\section{Loan to Deposit Ratio (LDR) Tidak Berpengaruh Terhadap Profitabilitas Bank}

Dari Uji t untuk variabel LDR (X1) terhadap Profitabilitas Bank (Y) mendapatkan hasil 1,605 dengan Signifikansi 0,111 yang nilainya lebih tinggi dari signifikansi $\alpha=5 \%(0,05)$ atau $0,111>$ 0,05 maka Ha ditolak, hal ini berarti variable Loan to Deposit Ratio (LDR) tidak berpengaruh atas Profitabilitas. 


\section{Non Performing Loan ( NPL) Berpengaruh Terhadap Profitabilitas Bank}

Uji t untuk variabel NPL (X2) terhadap Profitabilitas Bank (Y) mendapatkan hasil 3,990 dengan Signifikansi 0,00 nilainya lebih rendah dari signifikansi $\alpha=5 \%(0,05)$ atau $0,000<0,05$ dengan demikian Ha diterima, dapat berarti variable Non Performing Loan (NPL) berpengaruh kepada Profitabilitas.

\section{Net Interest Margin (NIM) Berpengaruh Terhadap Profitabilitas Bank}

Hasil Uji t untuk variabel NIM (X3) terhadap Profitabilitas Bank (Y) mendapatkan hasil 8,274 dengan Sig 0,00 yang mana lebih rendah dari tingkat signifikansi $\alpha=5 \%(0,05)$ atau $0,000<0,05$ sehingga Ha diterima yang artinya Net Interest Margin (NIM) berpengaruh kepada Profitabilitas.

\section{KESIMPULAN DAN SARAN}

\section{Kesimpulan}

Dari hasil olah data dan uji statistik yang sudah dilakukan, maka ditarik suatu kesimpulan bahwa Loan to Deposit Ratio (LDR) dinyatakan tidak berpengaruh atas Profitabilitas Bank, sedangkan Non Performing Loan (NPL) dan Net Interest Margin (NIM) dinyatakan berpengaruh kepada Profitabilitas Bank

\section{Saran}

1. Penelitian berikutnya diharapkan dapat menggunakan Objek penelitian yang berbeda

2. Penelitian berikutnya diharapkan untuk menambahkan variabel independent lainnya yang dapat mempengaruhi Profitabilitas Bank.

3. Peneliti selanjutnya juga dapat memperpanjang periode pengamatan yang akan diteliti.

\section{DAFTAR PUSTAKA}

Ghozali, Imam (2018) Aplikasi Analisa Multivariate dengan Program IBM SPSS 25, edisi 9. Semarang: Badan Penerbit Universitas Diponegoro

Kasmir (2018), Analisis Laporan Keuangan.Edisi Revisi. Jakarta: PT. Rajagrafindo Persada

Prihadi, Toto (2019), Analisis Laporan Keuangan Konsep dan Aplikasi. Jakarta: Penerbit Gramedia Pusaka Utama

Sujarweni, V Wiratna (2017) Analisis Laporan Keuangan: Teori, Aplikasi dan Hasil Penelitian. Yogyakarta: Pustaka Baru Press

Sugiyono (2017) Metode Penelitian Bisnis: Pendekatan Kuantitatif, Kualitatif, Kombinadi dan R\&D. Bandung: CV Alfabeta

Risky Diba Avrita dan Irene Rini Demi Pangestuti (2016). Analisis Pengaruh Capital Adequacy Ratio (CAR), Loan to Deposit Ratio (LDR), Non Performing Loan (NPL), Net Interest Margin (NIM) dan Biaya Operasional Pendapatan Operasional (BOPO) terhadap Profitabilitas Bank.

Triana Anugrah dan Chicilia Nova Yatna (2019). Pengaruh Non Performing Loan (NPL), Loan to 
Deposit Ratio (LDR) Net Interest Margin (NIM), Biaya Operasional terhadap Pendapatan Operasional (BOPO) dan Capital Adequacy Ratio (CAR) terhadap Profitabilitas Bank Umum Konvensional Buku 4 Periode 2012-2016.

Undang-Undang No.10 Tahun 1998

Peraturan Bank Indonesia No.8/7/PBI/2011

Peraturan Bank Indonesia No.6/10/PBI/2004

Peraturan Bank Indonesia No.13/1/PBI/2011

Peraturan Bank Indonesia No.15/7/PBI/2013

Peraturan Bank Indonesia No.15/15/PBI/2013

Peraturan Bank Indonesia No.9/7/PBI/2007

Surat Edaran Bank Indonesia No.13/30/DPNP tanggal 16 Desember 2011

https://ojk.go.id

hrrps://bi.go.id 